\title{
THE SOCIOLOGIST'S PROFESSIONAL IDENTITY: CONTRIBUTIONS TO ITS ANALYSIS
}

\author{
Sandro Serpa ${ }^{1 *}$, Carlos Miguel Ferreira ${ }^{2}$ \\ ${ }^{1}$ Prof. Dr., University of the Azores, Faculty of Social and Human Sciences, Department of \\ Sociology; Interdisciplinary Centre of Social Sciences - CICS.UAc/CICS.NOVA.UAc; \\ Interdisciplinary Centre for Childhood and Adolescence - NICA - UAc, PORTUGAL, \\ sandro.nf.serpa@uac.pt \\ ${ }^{2}$ Prof. Dr., Interdisciplinary Centre of Social Sciences - CICS.NOVA, \\ carlosmiguelferreira32@gmail.com \\ ${ }^{*}$ Corresponding Author
}

\begin{abstract}
The (re)formulation of the sociologist's professional identity has been, and it is, a process of permanent search for legitimation and institutionalisation. This paper aims to discuss the sociologist's professional identity, thus seeking to add to a deepening of this subject. For this purpose, a bibliographic search was carried out on this topic, starting from the situation of Sociology in Portugal. Furthermore, the authors' experience in teaching and research in the area of Sociology and related social sciences of about 20 years was also used. It is concluded that, in analytical terms, it is possible to differentiate ideal type profiles of the sociologist's professional identity. Yet, there is the need to be aware, on the one hand, of the possibility that the same sociologist can share features of more than one type, and, on the other hand, of the fact that, over time, both the sociologist's professional identity and the typology itself may be subject to changes.
\end{abstract}

Keywords: sociologist, Sociology, professional identity, profession, professional socialisation, expertise.

\section{INTRODUCTION}

The processes of institutionalisation and legitimation of Sociology, as a science but also a profession (Hanemaayer, 2019), depend on epistemological and methodological reasons but also on social factors, such as "Cultural configurations, orientations and nature of political power and social conflicts, geopolitical situation, level of scientific development, university organisation, nature of the dominant 'social problems', modalities of inauguration of the discipline" (Cuin \& Gresle, 1995, p. 235).

In Portugal, it was only possible to develop Sociology, in a consistent and fully visible way, after the Revolution of April 25, 1974 (Pinto, 2013; Castelo, 2015), in an institutionalisation that seems undeniable (Ferreira \& Serpa, 2017; Neto, 2013). This institutionalisation begins in the Public University (Almeida, 1999), which does not prevent the acknowledgement of niches that worked in this scientific area in the previous period, called Estado Novo (Ágoas, 2013).

According to Almeida (1994), in the first half of the 1990s the professionalization of Sociology in Portugal 
was "in a phase of great growth and affirmation" (p. 219). Sociologists were, at this time, perceived as "highly qualified, grounded on extensive study and on specific and specialised intellectual training, and are provided in exchange for remuneration. The preparation for the exercise of the profession is officially certified (by the schools that grant the degrees) and professional sociologists have their associations, which aim to guarantee their organisation, to ensure the advancement of the cognitive, technical and deontological standards of the professional practice of sociology, and to promote their acknowledgment" (p. 219). These professionals also performed "professional roles in teaching and research, but also in organisations and companies, municipalities and regional development agencies and bodies, in social development, social insertion, in culture and communication" (pp. 220-221).

In this context, "The main instrument of wide reproduction of the profession are the degrees in sociology" (Almeida, 1994, p. 221), but also teaching and research, such as academic studies - either commissioned or for career progression reasons -, Congresses and Meetings of Sociology debate, and publications. Almeida (1994) even considered that the increase in both the number of sociologists and their professional insertion and public and media visibility not only adds to the institutionalisation of Sociology itself in Portugal but also that these professionals will result in "new instruments that society possesses to think about itself and to deal with its problems" (p. 222).

More recently, a growing professional diversity in the area of Sociology in Portugal is visible (Carreiras, Freitas, \& Valente, 1999), which adds to a higher complexity of the sociologists' professional identity (Castelo, 2015, Egreja, 2016). The present research falls within this context. This article addresses the concept of professional identity, directing it to the sociologists' professional identity and focusing, in this point specifically, the sociologist profession and the sociologists' professional identity profiles, drawing from the conclusions some contributions for the analysis of this subject.

\section{METHODS}

This paper aims to discuss the sociologist's professional identity, thus adding to a deepening of this subject. For this purpose, a bibliographical search was carried out on this topic, starting from the situation of Sociology in Portugal and using the authors' experience in teaching and research in the area of Sociology and related social sciences of about 20 years.

\section{PROFESSIONAL IDENTITY}

This text does not seek to carry out a theoretical discussion on the complex concept of Identity (Zanatta, 2011; Alaoui \& Abakouy, 2017). Yet, in short, identity may be considered here as "a dynamic and relational process that considers the interaction of individuals in the various spheres of action and that must be linked to the social trajectories in which individuals build their identity" (Zanatta, 2011, p. 51).

By definition, identity(ies) is/are never built once and for all (Zanatta, 2011, Dubar, 1997, Castelo, 2015). According to Dubar (1997), identity is the product of socialisation processes, but also, and concurrently, "through the identity strategies developed in the institutions which individuals are part of, and for whose real transformation they contribute. This identity construction takes on particular importance in the field of work, employment and training, which has gained a strong legitimacy for the recognition of social identity and the ascription of social status" (p. 118).

In this analysis, the sociologist's professional identity results, to a large extent, from his/her academic/educational socialisation and from his/her professional socialisation.

\section{SOCIOLOGISTS' PROFESSIONAL IDENTITY}

\subsection{Sociologist Profession}

According to Gresle (1990), a number of criteria are usually used in the definition of profession, from which the author highlights "the specialisation of knowledge, which brings along a precise and autonomous determination of the rules of activity; higher level intellectual training, which presupposes the existence of duly acknowledged training schools; an ideal of service, which calls for the establishment of a code of ethics and its review by the peers" (p. 197).

Currently, there is a very close relationship between the importance of professions and the society where they are performed (Carvalho, Correia, \& Serra, 2018; Dubar, 1997; Gonçalves, 2007).

Specifically, with regard to Sociology, it is a science and a profession (Costa, 1988). As a science, it is a pluriparadigmatic disciplinary area that addresses necessarily complex issues (Pinto, 2013; Ferreira \& Serpa, 2017; Javeau, 1998; Cuin \& Gresle, 1995); as a profession, it "has the capacity to carry out studies in 
the framework of academic examinations, within the scope of research and development (R\&D) institutions, on the basis of national and community public tenders and funding, and also in terms of the provision of services contracted by public or private entities. It is a science-based activity, with a set of principles of professional ethics and a corporate sense of partnership, not essentially turned on itself, but because it seeks to discuss among peers issues of analysis and interpretation of social life and its dynamics" (Veloso, Freire, Oliveira, \& Lopes, 2012, p. 87).

According to Caria, César and Biltes (2012), there is a tendency to dichotomise science as theory and profession as practice, offering the example of the Sociology vs. Social Work polarisation: "• professionalisation of a deductive nature - which tends to occur with sociologists and which would guarantee the symbolic dominance of the activity -, which starts from the statements and competences of a monodisciplinary and scientific basis to a professional experience outside the academy, which is multiple and plural from the functional point of view; • professionalisation of an intuitive nature - that would occur with social workers and would more easily ensure the practical mastery of the activity -, which builds on accrued and professional experience outside the academy, on competence building and varied applied knowledge for activities with a high level of specificity and functional constraint, seeking in parallel a better and more convergent scientific basis" (p. 4). The authors continues, "we think that we will only be able to begin bridging the gap between the symbolic domain of analysis (of explanation) of reality and the practical domain of intervention (of research) in situation (inside the academy or outside the academy), if we put forth the hypothesis that there is a duality of knowledge and competences in both types of the use of knowledge" ( $p$. 14).

Capucha (1999), in his analysis of the sociologist in the evaluation of projects, programs and social policies, offers some features that are critical for the sociologist-evaluator, which, we believe, can be used, with a relative degree of importance, to carry out any profession: the scientific competence; the pedagogical competence; the relational and organisational competence (pp. 170 and 171).

\subsection{Sociologists' Professional Identity Profiles}

Castelo (2015), building on the work of authors such as Costa (1988) and Burawoy (2007), among others, develops a very relevant and heuristic analytical model for the analysis of identities in the exercise of Sociology (Cf. Castelo, 2015) "to understand the construction of identities and roles of Portuguese intra- and extra- academic sociologists" (p. 135). The author (Castelo, 2015, p. 151) puts forth the following proposals of two sociological paradigms as ideal types (Serpa, 2018). The first one is the Organic, "Centred/focused on the other(s); Objectives: to create knowledge/intervention of scientific quality and bilateral action and communication with the 'other(s)'; Dialogue with other fields of social reflection; Participation of the agents and promotion of reflexivity and expression spaces; Establishment of networks and partnerships with the agents of social change; Transparent methodological strategies that allow forms of engagement and expression on the part of the agents involved; Dissemination to diversified audiences". The second sociological paradigm is the Traditional, "Centred/focused on the expert; Objectives: to create knowledge/intervention of scientific quality and/or unilateral communication with the 'other'; Disciplinary/scientific; Implementation carried out by experts or professionals; Experts establish objectives, methodology and conclusions; Formal and opaque methodology; Specific dissemination to the audience directly involved".

Castelo (2015) presents the profiles of the exercise of Sociology, depicted on Table 1, based on the following dimensions: academic/extra-academic, crossed with instrumental/ reflexive.

Table 1. Profiles of the Exercise of Sociology

\begin{tabular}{|c|c|c|c|c|}
\hline \multirow{1}{*}{} & \multicolumn{2}{|c|}{ Academic } & \multicolumn{2}{c|}{ Extra-Academic } \\
\cline { 2 - 4 } & $\begin{array}{c}\text { Traditional } \\
\text { paradigm }\end{array}$ & Organic paradigm & Traditional paradigm & Organic paradigm \\
\hline \multirow{3}{*}{ Instrumental } & \multicolumn{2}{|c|}{$\begin{array}{c}\text { Academic-theoretical } \\
\text { Main objective: to solve sociological } \\
\text { puzzles/regular science }\end{array}$} & $\begin{array}{c}\text { Assessment } \\
\text { To solve problems in concrete social } \\
\text { realities/orders or contractual relationships } \\
\text { with extra-academic institutions }\end{array}$ \\
\cline { 2 - 5 } & Oracle & Connected to other & Applied & Clinical \\
\hline
\end{tabular}


IJASOS- International E-Journal of Advances in Social Sciences, Vol. V, Issue 14, August 2019

\begin{tabular}{|c|c|c|c|c|}
\hline & & types & & \\
\hline Reflexive & $\begin{array}{r}\text { Acad } \\
\text { Main objective } \\
\text { discussic } \\
\text { academic }\end{array}$ & $\begin{array}{l}\text { c-critical } \\
\text { stimulate internal } \\
\text { nd reflexivity } \\
\text { ro-revolutions }\end{array}$ & $\begin{array}{r}\text { Main objective: to } \\
\text { external reflexivity } \\
\text { with sev }\end{array}$ & $\begin{array}{l}\text { liscussion and } \\
\text { mmunicational } \\
\text { ces }\end{array}$ \\
\hline & $\begin{array}{l}\text { Consider only } \\
\text { academic } \\
\text { knowledge }\end{array}$ & $\begin{array}{l}\text { Encompass extra- } \\
\text { academic } \\
\text { knowledge }\end{array}$ & Commentator & Talkative \\
\hline
\end{tabular}

Source: Castelo (2015, p. 153).

It should be noted that not only can a sociologist be inserted simultaneously in several of these profiles of the exercise of Sociology, as this can vary in time.

In terms of projecting the future, "If we put aside the difficulties that result from restrictions on public funding for research and a continuing resistance to career stabilisation with a minimum of prospects - and these difficulties are real -, the main risk that the most prepared researchers face today will be, I believe, as I have already suggested, the fact that they will have to live with processes of paradigmatic normalisation, which, as we all know, feed (and are fed on) various intellectual dismissals: in terms of the selection of objects (due to the imposition of eligibility criteria often lacking an earnest epistemological grounding), in terms of the general design of projects (by devaluing the moment of theoretical grounding of the research), in terms of observational research strategies (due to basic mistrust in less conventional methodologies) and even in terms of the manner of exposure (the strictly formal limitations which the publication of scientific works is increasingly subject to are known)" (Pinto, 2013, p. 718).

In summary, and being also applicable to the sociologists' professional identity, the challenge is the construction of the individuals' professionalism, which implies the articulation of three processes: "- the process of initial and continuous training of competences through the articulation of their diverse origins: formalised knowledge, know-how, experience; - the process of building and developing jobs and their codification in the employment systems; - the process of recognition of competences, resulting from the game of professional relationships" (Dubar, 1997, p. 156).

This is a process in which there is competition even between Sociology and other scientific areas, even from the social sciences field (Egreja, 2016), concurrently with some fragmentation of Sociology itself (Sallum, Jr., 2005). Bögenhold (2017) sustains that "Instead of coherence, sociology presents itself as a patchwork of fragmented interests, topics and approaches" (p. 32).

\section{CONCLUSION}

The (re)formulation of the sociologist's professional identity (Butollo, 2017) has been, and it is, a process of permanent search for legitimation and institutionalisation. Regarding the sociologist's professional identity, it is concluded that it is analytically possible to distinguish several ideal type profiles of the sociologist's professional identity. Their professional identities are grounded on the three identified axes of type of training, jobs kind and social recognition, regarding the relative individual autonomy, However, there is the need to be aware, on the one hand, of the possibility that the same sociologist may share features of more than one type, and, on the other hand, of the fact that, over time, both the sociologist's professional identity and the typology itself may be subject to changes. Castelo (2015) advocates "the construction of his/her path towards professionalisation and towards the construction of competences and knowledge, in a training context in which there are several hypothetically possible paths, through mechanisms that may be used with greater or lesser awareness; different types of self-identification with regard to training and/or profession; and, finally, different professional cultures concerning the essence of sociology (with consequences for selfidentification as a sociologist, the way of dealing with extra-academic knowledge and with the sociologists who generate it) and as ways of conducting, working and disseminating work that may be translated into paradigms about how to work" (p. 156).

Ultimately, and as Cuin and Gresle (1995) maintain, "Being a social phenomenon, sociology remains a powerful 'indicator' of the deep orientations of the societies that welcome it, and a fortiori of those that reject it. An instrument of knowledge of society for itself only seems possible when it really wishes to know itself, that is, when intellectual freedom and political democracy rule" (p. 237). 


\section{ACKNOWLEDGMENT}

We would like to thank to the Editor and Reviewers for their comments and suggestions.

\section{NOTE}

A similar version of this paper was published in: Serpa, S., \& Ferreira, C. M. (2019). The sociologist's professional identity: contributions to its analysis. Abstracts \& Proceedings of SOCIOINT 2019 - 6th International Conference on Education, Social Sciences and Humanities, 24-26 June 2019, pp. 698-703. İstanbul, Turkey: OCERINT- International Organization Center of Academic Research.

\section{FUNDING}

University of Azores, Interdisciplinary Centre of Social Sciences-CICS.UAc/CICS.NOVA.UAc, UID/SOC/04647/2013, with the financial support of the FCT/MEC through national funds and when applicable co-financing from the FEDER under the PT2020 Partnership Agreement.

\section{REFERENCE LIST}

Ágoas, F. (2013). Narrativas em perspetiva sobre a história da sociologia em Portugal [Narratives in perspective on the history of Sociology in Portugal]. Análise Social, 206, x/viii (1st.), 221-256.

Alaoui, Y., \& Abakouy, M. (2017). L'identité: De la sociologie aux sciences sociales [Identity: From sociology to social sciences]. Barataria. Revista Castellano-Manchega de Ciencias Sociales, 22. doi:10.20932/barataria.v0i22.310.

Almeida, A. N. (1999). Uma introdução. Sociologia, sociólogos e práticas profissionais. Percursos de construção da identidade no Portugal democrático [An introduction. Sociology, sociologists and professional practices. Paths of identity construction in democratic Portugal]. In H. Carreiras, F. Freitas, \& I. Valente, I. (Eds.). Profissão sociólogo [Profession sociologist] (pp. 1-10). Oeiras: Celta Editora.

Almeida, J. F. de (1994). Introdução à Sociologia [Introduction to Sociology]. Lisboa: Universidade Aberta.

Bögenhold, D. (2017). The order of social sciences: Sociology in dialogue with neighbouring disciplines. The Journal of Philosophical Economics: Reflections on Economic and Social Issues, XI, 1, 27-52.

Burawoy, M. (2007). For public sociology. In A. Abbot et al. (Eds.), Public Sociology: Fifteen eminent sociologists debate politics \& the profession in the twenty-first century (pp. 23-64). California, USA: University of California Press.

Butollo, F. (2017). Sociology as science and action. Österreichische Zeitschrift Für Soziologie, 42(1), 91-94. doi:10.1007/s11614-017-0258-6. Report on the 3rd ISA forum of sociology in Vienna 2016 "The futures we want: Global sociology and the struggles for a better world".

Capucha, L. M. A. (1999). O sociólogo na avaliação de projectos, programas e politicas sociais [The sociologist in the evaluation of social projects, programs and policies]. In H. Carreiras, F. Freitas, \& I. Valente, I. (Eds.). Profissão sociólogo [Profession sociologist] (pp. 165-173). Oeiras: Celta Editora.

Caria, T. H., César, F., \& Biltes, R. (2012). A profissionalização da Sociologia e o uso dualístico das Ciências Sociais [The professionalization of Sciology and the dualistic use of Social Sciences]. Configurações, 9, 15-36. doi:10.4000/configuracoes.1083.

Carreiras, H., Freitas, F., \& Valente, I. (Org.) (1999). Profissão sociólogo [Profession sociologist]. Oeiras: Celta Editora.

Carvalho, T., Correia, T., \& Serra, H. (2018). Professions under suspicion: what role for professional ethics and commitment in contemporary societies? Sociologia, Problemas e Práticas, 88, 9-25. doi:10.7458/SPP20188814795.

Castelo, L. P. (2015). Construções identitárias dos sociólogos portugueses: Uma proposta de modelo analítico [Identity constructions of Portuguese sociologists: A proposal for an analytical model]. Sociologia On Line, 9, 133-160.

Costa, A. F. (1988). Cultura profissional dos sociólogos [Professional culture of sociologists]. Sociologia, 
Problemas e Práticas, 5, 107-124.

Cuin, C.-H., \& Gresle, F. (1995). História da Sociologia [History of Sociology]. Lisboa: Publicações Dom Quixote.

Dubar, C. (1997). A socialização. Construção das identidades sociais e profissionais [Socialisation. Construction of social and professional identities]. Porto: Porto Editora.

Egreja, C. (2016). O ensino da sociologia em cursos superiores de outras áreas de formação: A perspetiva de docentes e diretores [The teaching of sociology in higher education programmes in other areas of training: The perspective of teachers and directors]. Sociologia, Problemas e Práticas, 82. doi:10.7458/spp2016827449.

Ferreira, C., \& Serpa, S. (2017). Challenges in the teaching of Sociology in higher education. Contributions to a discussion. Societies, 7(4), 30. doi:10.3390/soc7040030.

Gonçalves, C. M. (2007). Análise sociológica das profissões: Principais eixos de desenvolvimento [Sociological analysis of professions: Main axes of development]. Sociologia, Revista da Faculdade de Letras da Universidade do Porto, 17, 177-223.

Gresle, F. (1990). Profissão [Profession]. In R. Boudon, P. Besnard, M. Cherkaoui, \& B.-P. Lécuyer (Dirs.). Dicionário de Sociologia [Dictionary of Sociology] (pp. 197-198). Lisboa: Publicações Dom Quixote.

Hanemaayer, A. (2019). Symposium Introduction: Challenges for Theorizing in the Profession of Sociology. Canadian Review of Sociology/Revue Canadienne de Sociologie, 56(1), 118-119. doi:10.1111/cars.12233

Javeau, C. (1998). Lições de Sociologia [Lessons of Sociology]. Oeiras: Celta Editora.

Pinto, J. M. (2013). Da sociologia como profissão à sociologia crítica. Entrevista com José Madureira Pinto por Renato Miguel do Carmo e Virgílio Borges Pereira [From sociology as a profession to critical sociology. Interview with José Madureira Pinto conducted by Renato Miguel do Carmo and Virgílio Borges Pereira]. Análise Social, 208, xlviii (3.), 685-720.

Neto, H. V. (2013). Principais estádios evolutivos da sociologia em Portugal [Main evolutionary stages of sociology in Portugal]. Sociologia, Revista da Faculdade de Letras da Universidade do Porto, XXVI, 37-59.

Sallum Jr., B. (2005). O futuro das ciências sociais. A sociologia em questão [The future of the social sciences. Sociology in question]. Sociologia, Problemas e Práticas, 48, 19-26.

Serpa, S. (2018). Ideal type in sociological research. Sociology International Journal, 2(5), 398-399. doi:10.15406/sij.2018.02.00075.

Veloso, L., Freire, J., Oliveira, L., \& Lopes, N. (2012). Questões deontológicas e de metodologia de investigação em sociologia: O caso do interesse público e das profissões [Deontological and research methodology issues in sociology: The case of the public interest and professions]. Sociologia, Problemas e Práticas, 69. doi:10.7458/spp201269788

Zanatta, M. S. (2011). As teias da identidade: Contribuições para a discussão do conceito de identidade na teoria sociológica [The webs of identity: Contributions to the discussion of the concept of identity in the sociological theory], Perspectiva Erechim, 35(132), 41-54. 